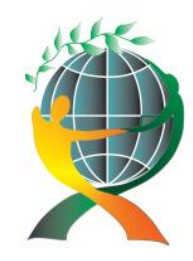

\author{
(online) $=$ ISSN $2285-3642$ \\ ISSN-L = $2285-3642$ \\ Journal of Economic Development, Environment and People \\ Volume 1, Issue 2, 2012 \\ URL: http://jedep.spiruharet.ro \\ e-mail: office jedep@spiruharet.ro
}

\title{
The Value of Decentralisations in Wastewater Management: Gauteng Province Case Study, South Africa
}

\author{
Cornelius (Chris) Reynders ${ }^{1}$, Harmony Musiyarira ${ }^{2}$, Prvoslav Marjanovic ${ }^{3}$ \\ ${ }^{1}$ C Reynders Consulting, Private Bag X43, Wilropark, 1731 South Africa, \\ creynders consulting@telkomsa.net \\ 2 Polytechnic of Namibia, P Bag 13388, Windhoek, Namibia. \\ 3 Educons University, Sremska Kamenica, Serbia and Institute for the \\ Development of Water Resources "Jaroslav Cerni", Belgrade, Serbia
}

\begin{abstract}
In a semi-arid water scarce country like South Africa, the efficient use of limited water resources and measures to extend the service value of these resources is a prerequisite for achieving sustainable development.

The conventional supply-sided management approach to water supply causes increased wastewater generation with accompanied increased pollution loads requiring higher levels of mitigation environmental pollution. Where disposal of wastewater treatment effluent takes place in rivers and natural water bodies, the lack of adequate natural compensating capacity of such water bodies typically result in severe ecological damage of the aquatic environment. With a shift of emphasis to a sustainable demand side management approach (as opposed to a supply side one), the avoidance of water wastage and high wastewater generation represents both resource conservation and environmental protection friendly approaches and contribute to overall sustainability. The integrated nature of water supply and wastewater management systems require an approach that considers these systems holistically. A new paradigm for water management is therefore needed to ensure that the issues of waste disposal and pollution are dealt with in a sustainable manner taking into account the emerging objectives of modern society for resource conservation and environmental protection.

A balance therefore has to be found between the uses of additional fresh water resources as a means of satisfying en ever increasing water demand on the one hand and alternative unconventional resource exploration and employment, without the risk of depletion of natural available fresh water resource flow, irreversible harm to the environment and social and economic constraints.

This paper explores wastewater and grey water reuse as unconventional resources in a qualitative manner within this balancing equation. It further proposes a methodology for deriving monetary indicator values for wastewater reuse by internalizing negative environmental impacts. This is achieved through application of Lagrangian
\end{abstract}




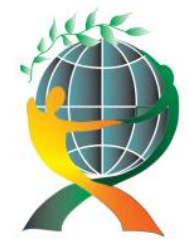

\author{
(online) $=$ ISSN $2285-3642$ \\ ISSN-L = $2285-3642$ \\ Journal of Economic Development, Environment and People \\ Volume 1, Issue 2, 2012 \\ URL: http://jedep.spiruharet.ro \\ e-mail: office jedep@spiruharet.ro
}

optimization of the treatment plant production function (output distance function) for deriving marginal prices of contaminant removal and resulting avoided pollution.

Keywords: Water resource protection, Sustainable wastewater management, Centralized wastewater management, Decentralized wastewater management, Production (output distance) function, environmental benefits valuing

\title{
JEL Codes: Q25, Q28, Q53, Q56
}

\section{Introduction}

In a semi-arid water scarce country like South Africa, the efficient use of the limited water resources and measures to extend the service value of these resources is a pre-requisite for achieving sustainable development. Constant pressure exists to explore new resources to meet the ever increasing demand posed by growth in population. Urban areas being centres of high economic activity not only attract new industries because of viable financial prospects and readily available resources, but also large numbers of people hoping to secure a better future.

From the UN population projections (2009) given in Figure 1 it is evident that the world urban population has moved beyond the 50\% mark since 2007 (equal urban and rural populations) and is expected to reach nearly $60 \%$ by 2030 . Furthermore, for developed countries the urban populations will approximately be $75 \%$ by 2010 and $80 \%$ by 2030 , while for developing countries, the urban population is expected to be around $45 \%$ in 2010 and reach $55 \%$ by 2030 . For the continent of Africa the population residing in urban areas is expected to reach $50 \%$ by 2030 .

Based on the population data mentioned, the rate of urbanization in developing countries in the next decade or two is expected to be about twice that of developed countries. This surge of growth in city populations will result in urban areas becoming demand nodes where ever increasing water supply and wastewater management will become a major challenge. This will apply increased pressure, not only on infrastructure necessary for provision of water, but also on finite fresh water resources and the available natural resource flow relied on.

Furthermore, not only will the increased population place a large burden on resources, but the high rate of urbanization and accompanying population growth would result in increased urban sprawl and slum development phenomena which make the provision of water and sanitary services extremely difficult and costly. The United Nation MDG progress report (United Nations 2010), emphasizes that since 2000 the portion of urban inhabitants of the developing world living in slums have declined from 39 to $33 \%$ in 2010 . Even though some 200 million slum dwellers gained by obtaining access to a reasonable level of services and improved housing, in absolute terms the population living in slums has actually increased due to eradication measures being insufficient to offset the growth of more slum settlements. It is estimated that in 2010 slum inhabitants accounted for 830 million people compared to 760 million in the year 2000 . 


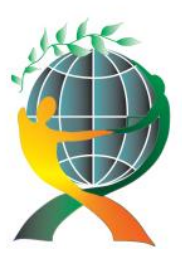

\author{
(online) $=$ ISSN $2285-3642$ \\ ISSN-L = $2285-3642$ \\ Journal of Economic Development, Environment and People \\ Volume 1, Issue 2, 2012
}

URL: http://jedep.spiruharet.ro

e-mail: office jedep@spiruharet.ro

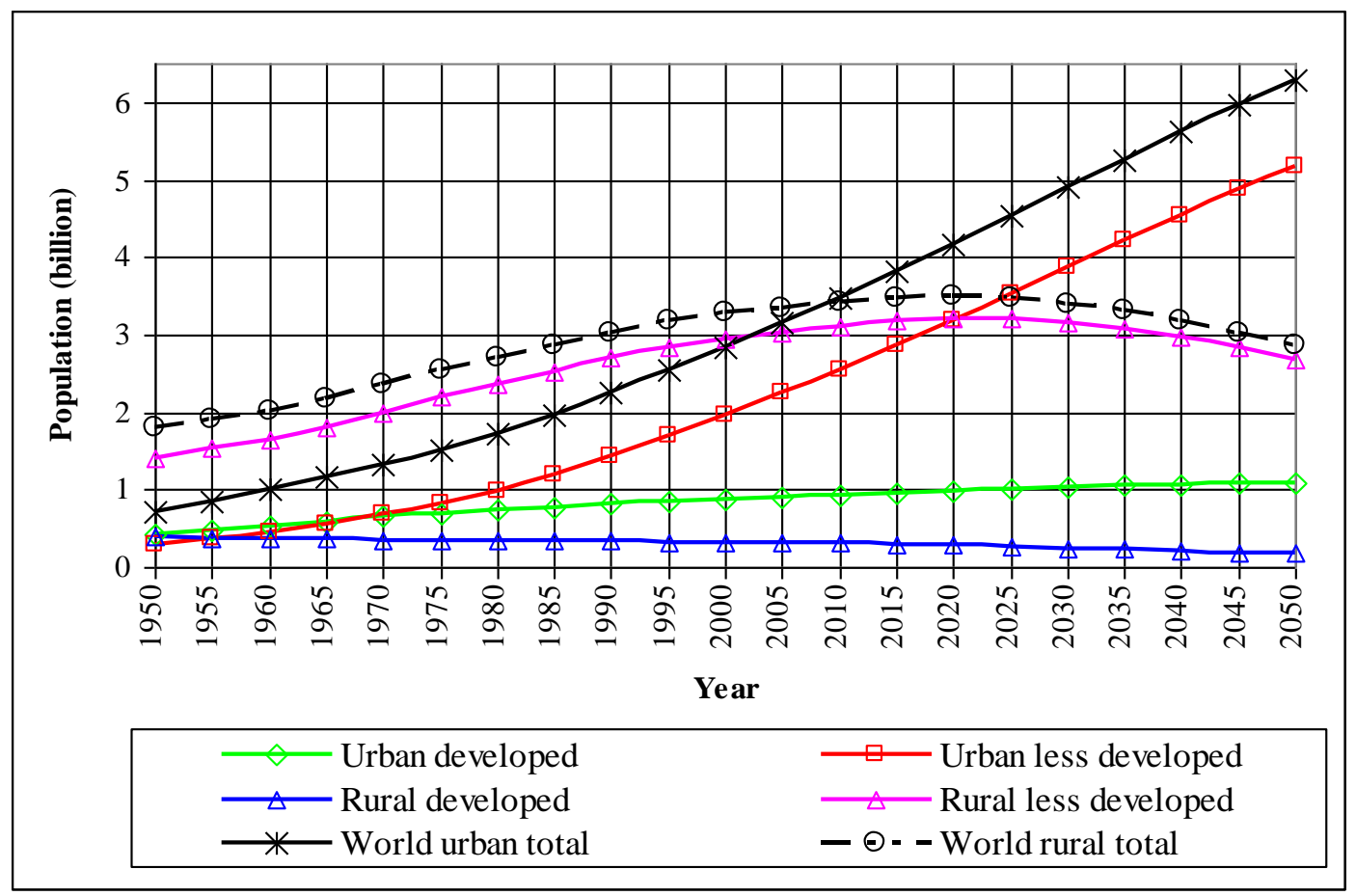

Fig. 1: Contributions of urban and rural populations for developed and less developed (or developing countries) (UN 2009)

Slum sections of urban communities in need of infrastructure will grow unless the provision of services and housing is either heavily subsidized by grants obtained from the international community and organizations. It is clear that the financial burden of the growing cities to render adequate essential services to all would simply become much more difficult. Under conditions of ever dwindling financial resources available to cities for the purpose of achieving the United Nations MDG and specifically the Goal 7 of a $50 \%$ reduction in people without safe water and appropriate sanitation by 2015 , would become very difficult if not unlikely to achieve.

This further emphasizes the urgency for a new water management approach and innovate ideas of options of technology to meet such goals. In essence what is needed is a paradigm shift from the conventional supply-sided water management approach. 


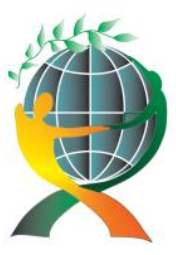

\author{
(online) $=$ ISSN $2285-3642$ \\ ISSN-L = $2285-3642$ \\ Journal of Economic Development, Environment and People \\ Volume 1, Issue 2, 2012 \\ URL: http://jedep.spiruharet.ro \\ e-mail: office jedep@spiruharet.ro
}

\section{Background}

The conventional supply-sided water supply management approach causes increased wastewater generation with accompanied increased pollution loads requiring higher levels of mitigation of environmental pollution. Where disposal of wastewater treatment effluent takes place in rivers and natural water bodies, the lack of adequate natural compensating capacity of such water bodies typically result in severe ecological damage of the aquatic environment. With a shift of emphasis to a sustainable demand sided management approach (as opposed to a supply sided one), the avoided water wastage and reduction of high volumes of wastewater generation represents both resource conservation and environmental protection benefits that contribute to overall sustainability. The integrated nature of water supply and wastewater management systems requires an approach that considers these systems holistically and linked with all elemental cycles closed within the given spatial and time frames with an objective to achieve "zero waste" scenarios as close as possible. Through a different and innovative new way of thinking (i.e. wastewater considered as valuable resource opposed to waste product) and proper related public health and social educational programmes, the paradigm shift required could obtain momentum with due consideration in water resource planning and management in the future.

The segmented approach of conventional water management with a mainly supply-side approach is under pressure. While having to meet growing need of water and sanitation services the conventional approach is not able to efficiently manage the reducing water resources and minimise both negative impacts on the environment and deterioration of the quality of life of urban inhabitants.

Although the effects on public health with these end-of-pipe systems have been very good, the sustainability of this approach continues to be questioned (Gijzen 1998). The use of large quantities of high quality water to convey concentrated human waste to centralized treatment facilities located on the outlying borders of cities and beyond makes resource management very difficult and limit fresh water resource conservation. For water scare countries this state of affairs is particularly not desirable or feasible from a sustainability point of view.

Sustainable water management will only be realized if both the waste minimization (reduced water consumption) and wastewater reuse concept are applied in an integrated way (Gijzen 1998). The need for a new approach is a result of the need to further protect the environment from pollution and to ensure that a high ecological diversity is maintained while at the same time natural resources are conserved by optimal use (Lettinga et al., 2001). Lettinga et al. also point out that the high cost of current conventional centralized systems is beyond the economic means of most developing countries. Countries with an average per capita GNP less than US \$ 1000 (1994 cost base), lack the resources to construct centralized systems and also cannot afford to maintain them. Furthermore, such systems have to be rebuild after 50 to 70 years at escalated increased expense which makes such systems even more unaffordable for developing countries.

A new paradigm for water management is needed to ensure that the issues of waste disposal and pollution are dealt with in a sustainable manner taking into account the emerging objectives of modern society for resource conservation and environmental protection. A balance therefore has to be found 


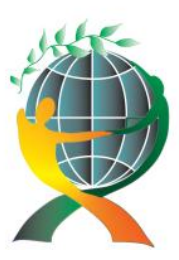

\author{
(online) $=$ ISSN $2285-3642$ \\ ISSN-L = $2285-3642$ \\ Journal of Economic Development, Environment and People \\ Volume 1, Issue 2, 2012 \\ URL: http://jedep.spiruharet.ro \\ e-mail: office jedep@spiruharet.ro
}

between the use of additional fresh water resources as a means of satisfying an ever increasing water demand on the one hand and alternative unconventional resource exploration and employment, without the risk of depletion of the natural available fresh water resource flow, irreversible harm to the environment and social and economic constraints.

\title{
2.1. Wastewater management systems in sustainable wastewater management
}

Two distinct types of wastewater management systems can be distinguished, namely centralized and decentralized systems. Centralised systems for wastewater treatment are considered by many in the water sector as the best practice for most communities because of the high level of reliability, established management framework and economies of scale giving an apparent (but not necessarily real) advantage of least cost per capita. Within the context of material flows, the centralized wastewater management system is an open ended loop system and is nowadays considered as being unsustainable in light of the high resource intensity (energy, inefficient use of water) and very little if any useful by-products recovery contained in wastewaters (Lettinga et al., 2001).

More recently the decentralised wastewater management approach is receiving renewed interest towards finding more affordable solutions and its prevention focus aimed at both resource protection and recovery and purposed redirection of water and nutrient cycles are facilitated at varying scale, such as from household to cluster or community levels. In addition, decentralised systems could be a more appropriate alternative to provide for tendency of sprawl development in cities towards the outer city fringes (Reynders et al., 2010).

The necessary technologies for treatment of wastewater to any existing regulatory standard (even to drinking water quality if needed) are available for the complete wastewater continuum system scale (Rocky Mountain Institute 2004). Technology is therefore not the constraint for seeking an optimal solution, but rather the needs of society and the water resources availability. Despite the fact that the technology may be available if it is unaffordable it cannot be considered to be sustainable.

With increased level of decentralized wastewater management onsite based resource recovery becomes more favourable and feasible, while at high centralized management scenarios offsite resource recovery through surface water reclamation are typical, groundwater recharge could potentially ensure optimal resource utilization (Reynders, 2011).

\subsection{Wastewater as unconventional resources}

The rationale and drivers for wastewater reuse as a non-conventional resource to supplement finite fresh water resources according to UNEP/GEC (2004) are: 1) optimal use (finite fresh water resources emphasizes the need of multiple use); 2) matching application and quality (ensures effective and efficient use of fresh water resources); 3) proximity (urban environment wastewater provides a readily available resource); 4) dependability (virtual constant wastewater generation even under drought conditions); 5) versatility (technology proven and tested for any required treatment levels); 6) safety (track record of no 


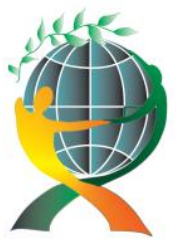

\author{
(online) $=$ ISSN $2285-3642$ \\ ISSN-L = $2285-3642$ \\ Journal of Economic Development, Environment and People \\ Volume 1, Issue 2, 2012 \\ URL: http://jedep.spiruharet.ro \\ e-mail: office jedep@spiruharet.ro
}

adverse health impacts ensured by appropriate quality monitoring); 7) water resource competing demands (mitigates food security increased agricultural demands); 8) fiscal responsibility (recognition of economic and environmental benefits); 9) public interest (increasing public awareness of negative environmental impacts of fresh resource overuse); 10) environmental and economic impacts of traditional resource approaches avoided (reservoir facilities and dams); 11) proven success track record (growth in successful number of reuse projects globally); 12) real cost of fresh water supplies (growing implementation of pricing structures being actual cost based); 13) more stringent water quality standards (increased cost makes direct reuse an economically viable alternative); 14) necessity and opportunity (suitable intervention under conditions of droughts, water shortages, etc.).

Wastewater effluent adequately treated could be used for urban uses (landscape, fire fighting etc) groundwater recharge, environmental enhancement, industrial and agricultural purposes. Potable urban use could be considered provided more advanced tertiary treatment processes are introduced.

The use of nutrients contained in wastewater would reduce the exploitation of a scarce phosphorus mineral resource as well as the high energy use for its mining and the nitrogen fixation process required for artificial fertilizer production and a vast array of negative environmental impacts of such production processes could also be avoided (Gijzen 2001).

Chemical energy present in wastewater in the form of carbonaceous matter with its decomposition has an inherent potential for energy generation. Appropriate technologies for extracting energy from wastewater, amongst others, are: 1) anaerobic digestion; 2) biofixation (plants, algae), and; 3) microbial fuel cells. Burton et al. (2009) pointed out that ease of separation of the energy from the wastewater is crucial to the feasibility of the process employed for energy recovery, i.e. biogas which separates naturally from wastewater while bioethanol requires energy intensive distillation for its recovery.

\title{
2.3. Intrinsic value recovery pathways - Reclamation, Reuse and Recycling
}

Wastewater reclamation, recycling and reuse are significant components of the hydrologic cycle in urban, industrial and agriculture areas as demonstrated in Figure 2. The quantity transferred via each pathway depends on the watershed characteristics, climatic and geo-hydrologic factors, degree of water use for various applications and degree of reclamation, reuse and recycling. 


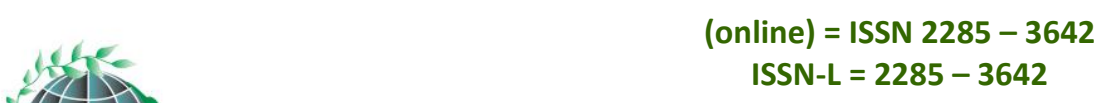

Journal of Economic Development, Environment and People

Volume 1, Issue 2, 2012

URL: http://jedep.spiruharet.ro

e-mail: office jedep@spiruharet.ro

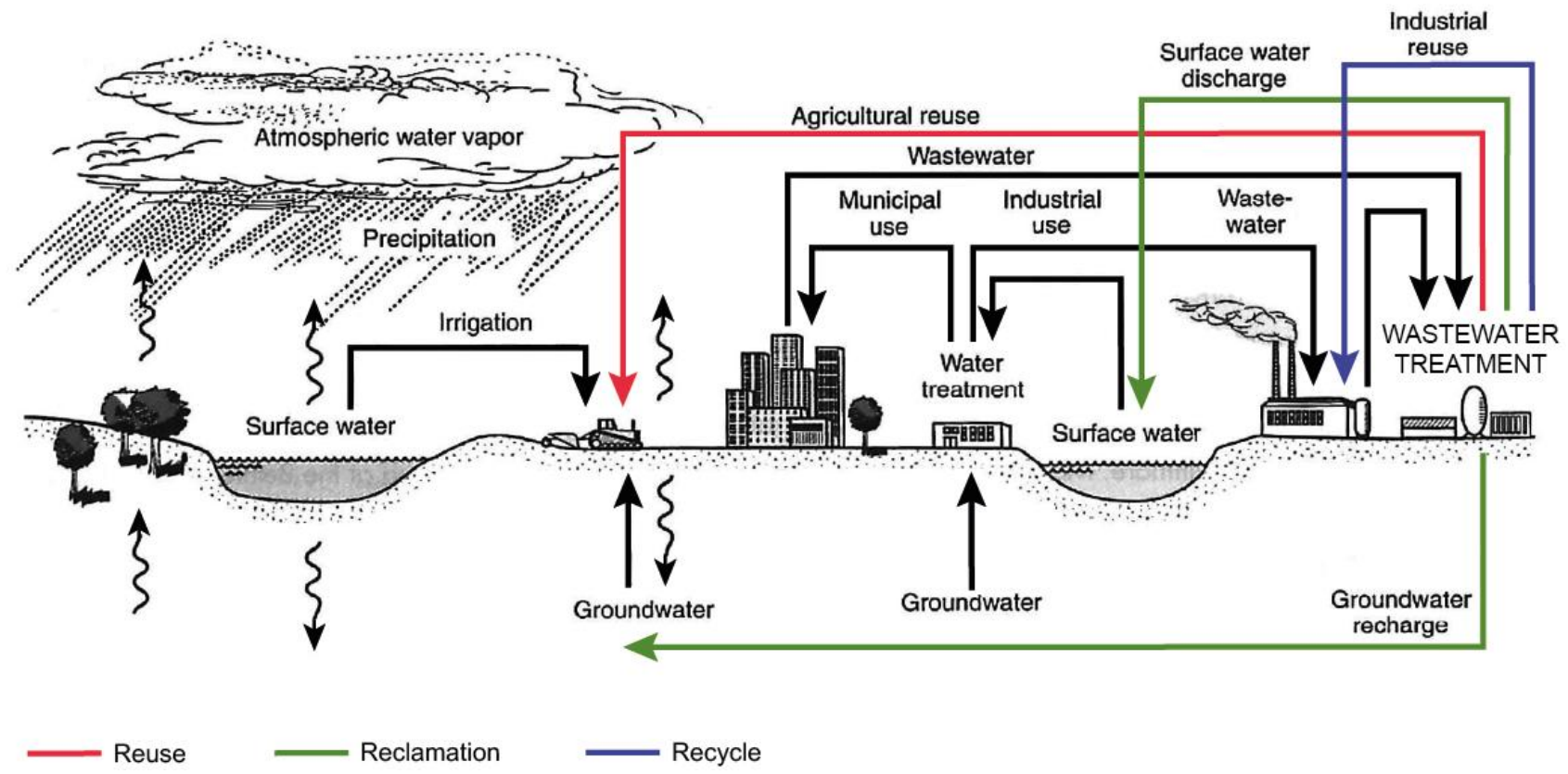

Fig. 2: Hydrologic cycle and the major intrinsic value recovery pathways (Reynders, 2011)

Various applications of wastewater reuse are possible and the reuse categories and examples thereof are given in Table 1.

Table 1: Wastewater reuses categories and application examples (UNEP/GEC, 2004)

\begin{tabular}{|l|l|}
\hline Category of reuse & Examples of applications \\
\hline $\begin{array}{l}\text { Urban use } \\
\text { Unrestricted }\end{array}$ & $\begin{array}{l}\text { Landscape irrigation of parks, playgrounds, school yards, } \\
\text { golf courses, cemeteries, residential green belts, snow } \\
\text { melting } \\
\text { Irrigation of areas with infrequent and controlled access } \\
\text { Restricted }\end{array}$ \\
Other & Frotection, disaster preparedness, construction \\
\hline
\end{tabular}




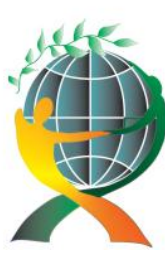

$$
\begin{gathered}
\text { (online) }=\text { ISSN } 2285-3642 \\
\text { ISSN-L }=2285-3642
\end{gathered}
$$

Journal of Economic Development, Environment and People

Volume 1, Issue 2, 2012

URL: http://jedep.spiruharet.ro

e-mail: office jedep@spiruharet.ro

\begin{tabular}{|l|l|}
\hline $\begin{array}{l}\text { Agricultural } \\
\text { Nood crops } \\
\text { consumed after processing }\end{array}$ & $\begin{array}{l}\text { Irrigation for crops grown for human consumption } \\
\text { Irrigation for fodder, fibre, flowers, seed crops, pastures, } \\
\text { commercial nurseries, sod farms }\end{array}$ \\
\hline $\begin{array}{l}\text { Recreational use } \\
\text { Unrestricted }\end{array}$ & $\begin{array}{l}\text { No limitation on body contact: lakes and ponds used for } \\
\text { swimming, snowmaking } \\
\text { Fishing, boating and other non-contact recreational } \\
\text { activities }\end{array}$ \\
\hline Environmental enhancement & $\begin{array}{l}\text { Artificial wetlands creation, natural wetland } \\
\text { enhancement and stream flow }\end{array}$ \\
\hline Groundwater recharge & $\begin{array}{l}\text { Groundwater replenishment for potable water, salt } \\
\text { water intrusion control, subsidence control }\end{array}$ \\
\hline Industrial reuse & $\begin{array}{l}\text { Cooling system water, process water, boiler feed water, } \\
\text { toilets, laundry, construction wash-down water, air } \\
\text { conditioning }\end{array}$ \\
\hline Residential use & Cleaning, laundry, toilet, air conditioning \\
\hline Potable reuse & $\begin{array}{l}\text { Blending with municipal water supply, pipe to pipe } \\
\text { supply }\end{array}$ \\
\hline
\end{tabular}

Despite the fact that technologies are available for adequate treatment to potable use quality and even higher than required standards, the concept of drinking wastewater still does not have wide public support. According to Dolnicar and Shafer (2009), there are several factors combined that hinder recycled water uptake for potable use. These include inadequate distribution infrastructure for supply (which applies to any reuse application as such), existing highly subsidized and comparatively low cost potable water resources, and a low level of community awareness of the limitations of freshwater resources, particularly in urban areas.

Grey water (all domestic/commercial wastewater excluding human excreta) reuse has great potential for fresh water resource conservation at household and public level environments (Dixon et al., 1999). As the total grey water fraction of combined domestic sewage is estimated to be around $75 \%$ by volume, from a fresh water conservation point of view approximately $30 \%$ to nearly $40 \%$ of the total household water consumption could be saved by reuse for flushing toilets and garden watering (Eriksson et al. 2002, Al- 


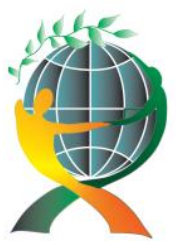

\author{
(online) $=$ ISSN $2285-3642$ \\ ISSN-L = $2285-3642$ \\ Journal of Economic Development, Environment and People \\ Volume 1, Issue 2, 2012 \\ URL: http://jedep.spiruharet.ro \\ e-mail: office jedep@spiruharet.ro
}

Jayyousi 2003, Li et al., 2009). In the case of public environments (such as offices and shopping malls) the proportion used for toilet flushing is as high as 48 to 63\% (Lazarova et al., 2003). The problem in such cases is the limited availability of grey water of such uses and most likely will require supplementation from potable water supplies for toilet flushing application of grey water. When limited volumes of grey water are available, reuse of the larger available wastewater flow would be more appropriate for achieving fresh water resource conservation.

With such applications only the "light grey water" fraction is used, excluding the "dark grey water" from kitchens (sinks and dishwashers) and laundry purposes. Kitchen (scullery) wastewater contains food wastes that would putrefy and cause bad odour and biological film build-up in reuse systems blocking pipes. Kitchen grey water accounts for about 5 to $12 \%$ of average household consumption and its omission from the grey water reuse source is therefore not significant (Christova-Boal et al., 1996, Li et al., 2009).

With regard to irrigational reuse, grey water provide only minor nutrient value, as the major fraction of nutrients is present in human excreta consisting of faeces plus urine.

Schemes or trails of grey water reuse for toilet flushing occurs mainly at household level (Australia, Canada, France, Germany and the UK) with instances of office buildings (Japan). Also instances of treated wastewater reuse for toilet flushing occurs such as in the USA, UK, Canada and Japan (Lazarova et al., 2003). There are a number of problems related to the reuse of untreated grey wastewater. There is a risk of spreading diseases when water is reused for e.g. toilet flushing or irrigation. Spreading of pathogenic microorganisms in the water in the form of aerosols generated as the toilets are flushed allow spreading and both inhaling and hand to mouth contact are dangerous (Eriksson et al. 2002).

Although social support does exist for reuse, there are reservations of its applications, in particular where direct personal contact and ingestion is concerned. According to the WHO (2006), the question of public acceptance of grey water reuse is less problematic compared to wastewater reuse. This is attributed to users being in contact with grey water at source (bath, shower and basin) and generally being considered by them as not being harmful and that no religious edicts prohibit its reuse.

If the treated final effluent could be perceived as being 'used water' rather than sewage or wastewater, it would go a long way towards fostering a different public and political perception of this potentially useful resource. A pioneer of the Namibian wastewater reuse project for potable use said: "water should not be judged by its history but by its quality" (Haarhoff, van der Merwe 1996). This is surely to be of fundamental importance when the issue of acceptance not for potable reuse alone but all applications of reuse is being dealt with by society. 


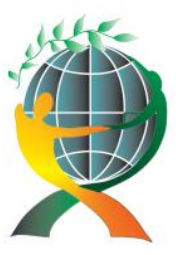

\author{
(online) $=$ ISSN $2285-3642$ \\ ISSN-L = $2285-3642$ \\ Journal of Economic Development, Environment and People \\ Volume 1, Issue 2, 2012 \\ URL: http://jedep.spiruharet.ro \\ e-mail: office jedep@spiruharet.ro
}

\section{Methodology for valuing intrinsic wastewater resource recovery}

The best way of effectively reducing the water footprint of any given nation is by reduction of water withdrawals through implementation of reuse and multiple water use. As alluded to previously, wastewaters should be seen as valuable resources which have intrinsic value for society and such value can and should be recovered. While issues of sustainability of wastewater management act as a main driver for intrinsic value recovery, this will only happen in practice if economic value of such recovery is possible and the conditions under which such recovery will be justifiable are clearly outlined, not only from a sustainability point of view but also in terms of economic parameters. What in fact is needed is a methodology for assessment of the economic evaluation of the intrinsic value recovery potential from wastewater for required feasibility analyses at wastewater treatment plant and wastewater management system levels.

For objective economic comparison and decision-making, both in the public and private domain, the value of water resources has to be based on an objective market related price. The major challenge in obtaining this is that water resources are generally considered a public good, are not traded in private markets nor subjected to the market price mechanism although a trend in this direction is well documented in the literature. The result is that water resources are considered to be of low market value and exploited (Birol et al., 2006). A further challenge is to account for the resource scarcity value (in terms of both quantity and quality) in addition to resource extraction costs. If scarcity is not recognized, high resource use, wastage and pollution of water resources are likely to be the end result.

In addition, factors also contributing to this value distortion of water resources, amongst others, are government subsidization and the practice of not accrediting polluting industries with environmental protection externality benefits achieved by them. To correct the value distortion of the water resources mentioned, all benefits obtained by use of water resources need to be captured in a total resource valuation.

The methods developed for determining environmental resource values are adequately covered in the literature. (Rocky Mountain Institute 2004, Birol et al., 2006). Among the group known as "indirect valuation" methods, the "production function" approach through analysis of a parameterized distance function was selected as basis of analysis of resource valuation. The "distance-function" approach, as opposed to a conventional production function one, was favoured because: 1) it allows modeling the joint production of multiple outputs; 2) aggregation of outputs or inputs are not required for deriving shadow price; 3 ) no assumptions of production process behaviour such as cost-minimization or profit-maximization have to be made for deriving shadow prices, and; 4) it allows for shadow price derivation based on the Shephard (1970) duality theory (Färe et al. 1993, O'Donnell, Coelli 2005).

The established methodology of using frontier functions to analyze production efficiency, known as Data Envelopment Analysis (DEA), was used in the analysis Farrell (1957). By exploring derivatives along the mentioned frontier of technology, shadow prices that support such technology are derived (Färe et al., 1993).

To employ the concept of production function valuing used in the industrial sector for pollution control and wastewater treatment situations, analogies are drawn between the desirable and undesirable outputs in 


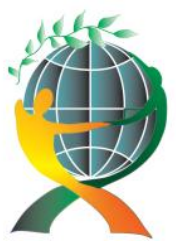

\author{
(online) $=$ ISSN $2285-3642$ \\ ISSN-L = $2285-3642$ \\ Journal of Economic Development, Environment and People \\ Volume 1, Issue 2, 2012 \\ URL: http://jedep.spiruharet.ro \\ e-mail: office jedep@spiruharet.ro
}

the two respective situations or "production processes". The wastewater treated effluent is considered analogous to a desirable production output of an industry, while contaminants removed for ensuring effluent quality are considered as undesirable outputs.

It should be noted that each particular situation is unique and requires a careful application of the analogy principle so as to ensure adequate problem formulation. With the appropriate application of the analogy principle a relevant problem formulation can be obtained for the thorough economic analysis of the different wastewater management system scenarios.

The distance function approach can be employed for both wastewater treatment level and wastewater management system level analyses for the same sewage catchment area (Reynders, 2011) and are illustrated in Figure 3. Provided the necessary data is available, distance function valuing can also be used for the analysis of a fully decentralised wastewater treatment system with each household operating their own "wastewater treatment facility". The result of such analyses can be used for comparison purposes of wastewater management of a particular, but using a virtual single centralized wastewater treatment plant as a replacement for all the individual decentralized system plants. The method can be extended to the comparative analysis of any set of scenarios of the wastewater management system composition (individual, cluster and block, central and regional plants). Such a scenario analysis can then be used to evaluate the net economic effects of utilizing different system configurations and technology options (Figure 4). Theoretically one could also begin to ask questions regarding the economic effects of choices between reclamation, reuse and recycle or a combination thereof and analyze the economic performance differences between surface and ground water reclamation strategies. 


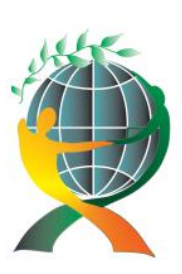

$$
\begin{gathered}
\text { (online) }=\text { ISSN } 2285-3642 \\
\text { ISSN-L = 2285 - } 3642
\end{gathered}
$$

Journal of Economic Development, Environment and People

Volume 1, Issue 2, 2012

URL: http://jedep.spiruharet.ro

e-mail: office jedep@spiruharet.ro

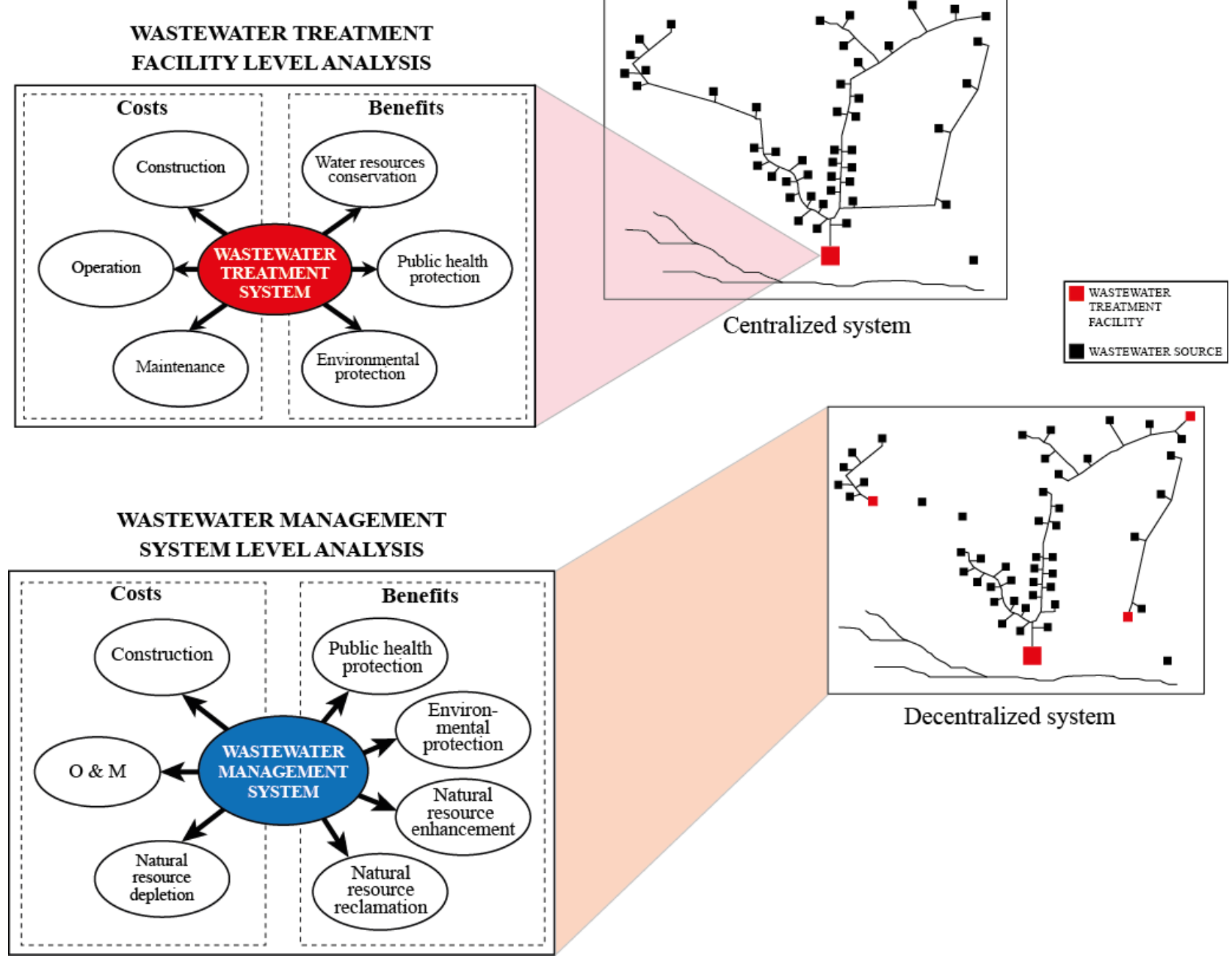

Fig. 3: Illustration of wastewater treatment level and wastewater management system level analysis (Reynders. 2011) 


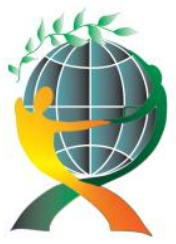

\author{
(online) $=$ ISSN $2285-3642$ \\ ISSN-L = $2285-3642$
}

Journal of Economic Development, Environment and People

Volume 1, Issue 2, 2012

URL: http://jedep.spiruharet.ro

e-mail: office jedep@spiruharet.ro

\title{
STRATEGIC CHOICES AND DISTANCE FUNCTION VALUATION METHOD
}

\begin{abstract}
Different system configurations have different potential for wastewater reclamation, reuse and recycling each with different economic, environmental and social inputs and outputs. By application of of the distance function valuing method, economic effects and implications can be evaluated for system configuration.

Once such an evaluation is carried out, ranking of scenarios by their economic performance (efficiency) can be determined and this could serve as input into the decision-making process.

It is noted that it would also be possible to analyse the effects of different technology

option choices within each system configuration scenario.

The approach is also amenable to evaluation with respect to making decisions to switch

from one system configuration to another or

from one set of technologies to another.
\end{abstract}

Total number of plants for a given area (PURE SYSTEMS)

Fraction of plants of a particular category

Total number of plants for a given area (MIXED SYSTEMS)
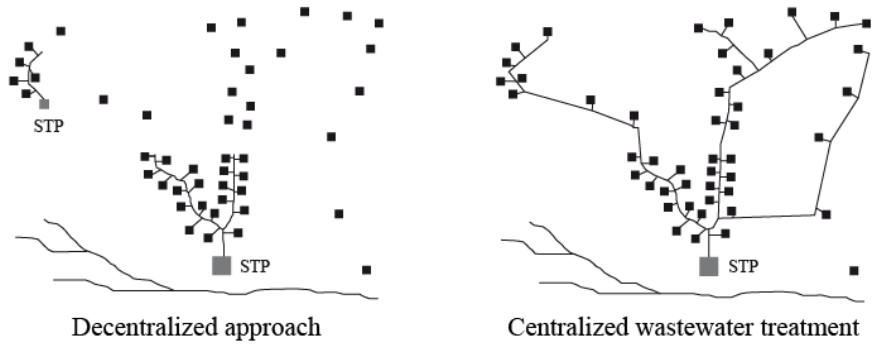

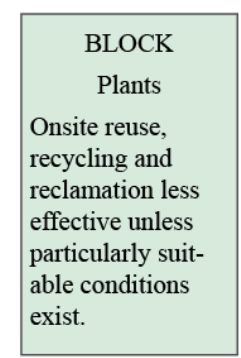

W

U

a

$\mathrm{b}$

\begin{tabular}{|l|}
\multicolumn{1}{|c|}{ CLUSTER } \\
\multicolumn{1}{c|}{ Plants } \\
Onsite reuse and \\
reclamation diffi- \\
cult to achieve. \\
Offsite reclama- \\
tion and reuse \\
feasible. \\
\hline
\end{tabular}

$\mathrm{X}$

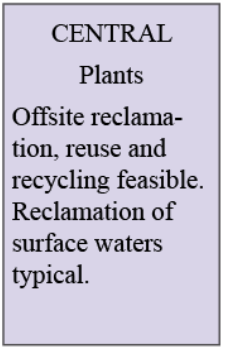

Y

$$
\mathbf{U}>\mathbf{W}>\mathbf{X}>\mathbf{Y}>\mathbf{Z}
$$

c

$$
\mathbf{U}>\mathbf{a U}+\mathbf{b W}+\mathbf{c X}+\mathbf{d Y}+\mathbf{e Z}>\mathbf{Z}
$$

Fig. 4: Strategic choices and distance function method application in wastewater management continuum (Reynders 2011)

\section{Case study: Wastewater reuse beneficiation at wastewater treatment facility level}

The indirect distance function approach was employed to jointly quantify and internalize environmental, public health and water resource conservation benefits of avoided pollution in the economic cost-benefit analysis of nine wastewater treatment facilities located in Gauteng Province South Africa. Inclusiveness of environmental, resource conservation and public health benefits here are due to these being fully achieved as a result of complete effluent reclamation and fully sewered wastewater catchments with final effluent disinfection.

The sequence of steps followed for environmental benefits valuing and subsequent economic analysis is outlined in Figure 5 and the analysis results obtained are given in Tables 2 to 6 and Figure 6 respectively. 


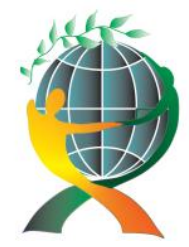

\author{
(online) $=$ ISSN $2285-3642$ \\ ISSN-L = $2285-3642$ \\ Journal of Economic Development, Environment and People \\ Volume 1, Issue 2, 2012
}

URL: http://jedep.spiruharet.ro

e-mail: office jedep@spiruharet.ro

Table 2: Output distance function optimal parameters

\begin{tabular}{|c|c|c|c|c|c|c|c|}
\hline \multicolumn{7}{|c|}{ Output distance function - optimal parameter values } \\
\hline Parameter & Value & Parameter & Value & Parameter & Value & Parameter & Value \\
\hline$\alpha_{0}$ & $-7.20 \mathrm{E}-03$ & $\gamma_{22}$ & $4.14 \mathrm{E}-03$ & $\gamma_{54}$ & $-1.05 \mathrm{E}-02$ & $\beta_{11}$ & $1.76 \mathrm{E}-03$ \\
\hline$\alpha_{1}$ & $2.24 \mathrm{E}-01$ & $\gamma_{23}$ & $-2.04 \mathrm{E}-02$ & $\gamma_{55}$ & $-9.51 \mathrm{E}-03$ & $\beta_{12}$ & $-2.07 \mathrm{E}-01$ \\
\hline$\alpha_{2}$ & $1.76 \mathrm{E}-01$ & $\gamma_{24}$ & $-4.30 \mathrm{E}-03$ & $\alpha_{11}$ & $4.85 \mathrm{E}-03$ & $\beta_{13}$ & $-8.39 \mathrm{E}-02$ \\
\hline$\alpha_{3}$ & $1.82 \mathrm{E}-01$ & $\gamma_{25}$ & $-1.27 \mathrm{E}-02$ & $\alpha_{12}$ & $1.33 \mathrm{E}-02$ & $\beta_{14}$ & $3.16 \mathrm{E}-01$ \\
\hline$\alpha_{4}$ & $2.13 \mathrm{E}-01$ & $\gamma_{31}$ & $1.59 \mathrm{E}-02$ & $\alpha_{13}$ & $3.63 \mathrm{E}-02$ & $\beta_{15}$ & $-4.79 \mathrm{E}-03$ \\
\hline$\alpha_{5}$ & $2.06 \mathrm{E}-01$ & $\gamma_{32}$ & $-1.36 \mathrm{E}-02$ & $\alpha_{14}$ & $-3.88 \mathrm{E}-02$ & $\beta_{22}$ & $3.44 \mathrm{E}-02$ \\
\hline$\beta_{1}$ & $-8.59 \mathrm{E}-02$ & $\gamma_{33}$ & $3.14 \mathrm{E}-03$ & $\alpha_{15}$ & $-1.56 \mathrm{E}-02$ & $\beta_{23}$ & $1.79 \mathrm{E}-01$ \\
\hline$\beta_{2}$ & $-4.63 \mathrm{E}-02$ & $\gamma_{34}$ & $-6.16 \mathrm{E}-03$ & $\alpha_{22}$ & $-1.36 \mathrm{E}-02$ & $\beta_{24}$ & $-2.14 \mathrm{E}-01$ \\
\hline$\beta_{3}$ & $-4.94 \mathrm{E}-02$ & $\gamma_{35}$ & $6.52 \mathrm{E}-04$ & $\alpha_{23}$ & $-1.65 \mathrm{E}-02$ & $\beta_{25}$ & $8.16 \mathrm{E}-02$ \\
\hline$\beta_{4}$ & $-8.53 \mathrm{E}-02$ & $\gamma_{41}$ & $-4.55 \mathrm{E}-02$ & $\alpha_{24}$ & $9.21 \mathrm{E}-03$ & $\beta_{33}$ & $2.12 \mathrm{E}-02$ \\
\hline$\beta_{5}$ & $-5.27 \mathrm{E}-02$ & $\gamma_{42}$ & $-2.59 \mathrm{E}-03$ & $\alpha_{25}$ & $7.59 \mathrm{E}-03$ & $\beta_{34}$ & $-1.13 \mathrm{E}-01$ \\
\hline$\gamma_{11}$ & $3.69 \mathrm{E}-02$ & $\gamma_{43}$ & $7.32 \mathrm{E}-04$ & $\alpha_{33}$ & $-3.08 \mathrm{E}-02$ & $\beta_{35}$ & $-1.95 \mathrm{E}-02$ \\
\hline$\gamma_{12}$ & $-4.01 \mathrm{E}-03$ & $\gamma_{44}$ & $2.44 \mathrm{E}-02$ & $\alpha_{34}$ & $1.22 \mathrm{E}-02$ & $\beta_{44}$ & $4.57 \mathrm{E}-03$ \\
\hline$\gamma_{13}$ & $-4.12 \mathrm{E}-03$ & $\gamma_{45}$ & $2.30 \mathrm{E}-02$ & $\alpha_{35}$ & $-1.19 \mathrm{E}-03$ & $\beta_{45}$ & $1.55 \mathrm{E}-02$ \\
\hline$\gamma_{14}$ & $-1.41 \mathrm{E}-02$ & $\gamma_{51}$ & $1.22 \mathrm{E}-02$ & $\alpha_{44}$ & $1.26 \mathrm{E}-02$ & $\beta_{55}$ & $-7.39 \mathrm{E}-02$ \\
\hline$\gamma_{15}$ & $-1.46 \mathrm{E}-02$ & $\gamma_{52}$ & $3.59 \mathrm{E}-03$ & $\alpha_{45}$ & $4.86 \mathrm{E}-03$ & & \\
\hline$\gamma_{21}$ & $3.32 \mathrm{E}-02$ & $\gamma_{53}$ & $4.18 \mathrm{E}-03$ & $\alpha_{55}$ & $4.34 \mathrm{E}-03$ & & \\
\hline
\end{tabular}

Table 3: WWTP output distance function values and shadow prices

\begin{tabular}{|l|c|c|c|c|c|}
\hline \multirow{2}{*}{ WWTP's } & $\begin{array}{c}\text { Output } \\
\text { distance }\end{array}$ & \multicolumn{4}{|c|}{$\begin{array}{c}\text { Shadow prices - undesirable outputs (ZAR/kg) } \\
\text { (assumed desirable output objective price = ZAR 1/m }{ }^{3} \text { ) }\end{array}$} \\
\cline { 3 - 6 } & function values & COD & SS & N & P \\
\hline Plant 1 & 0.999999218 & -0.03 & -0.09 & -2.49 & -6.57 \\
\hline Plant 2 & 0.999999252 & -0.05 & -0.14 & -1.38 & -7.87 \\
\hline Plant 3 & 0.999999269 & -0.07 & -0.11 & -2.38 & -8.98 \\
\hline Plant 4 & 0.999998613 & -0.11 & -0.29 & -6.27 & -21.19 \\
\hline Plant 5 & 0.999999898 & -0.05 & -0.22 & -3.72 & -13.57 \\
\hline Plant 6 & 0.999998548 & -0.06 & -0.18 & -5.35 & -21.94 \\
\hline Plant 7 & 0.999999347 & -0.05 & -0.19 & -1.94 & -8.96 \\
\hline Plant 8 & 0.999999152 & -0.08 & -0.33 & -3.59 & -16.67 \\
\hline Plant 9 & 0.999999565 & -0.09 & -0.29 & -2.01 & -7.58 \\
\hline
\end{tabular}




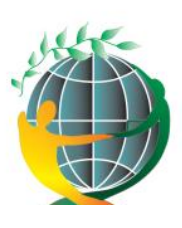

$$
\begin{gathered}
\text { (online) }=\text { ISSN } 2285-3642 \\
\text { ISSN-L = 2285 - } 3642
\end{gathered}
$$

Journal of Economic Development, Environment and People

Volume 1, Issue 2, 2012

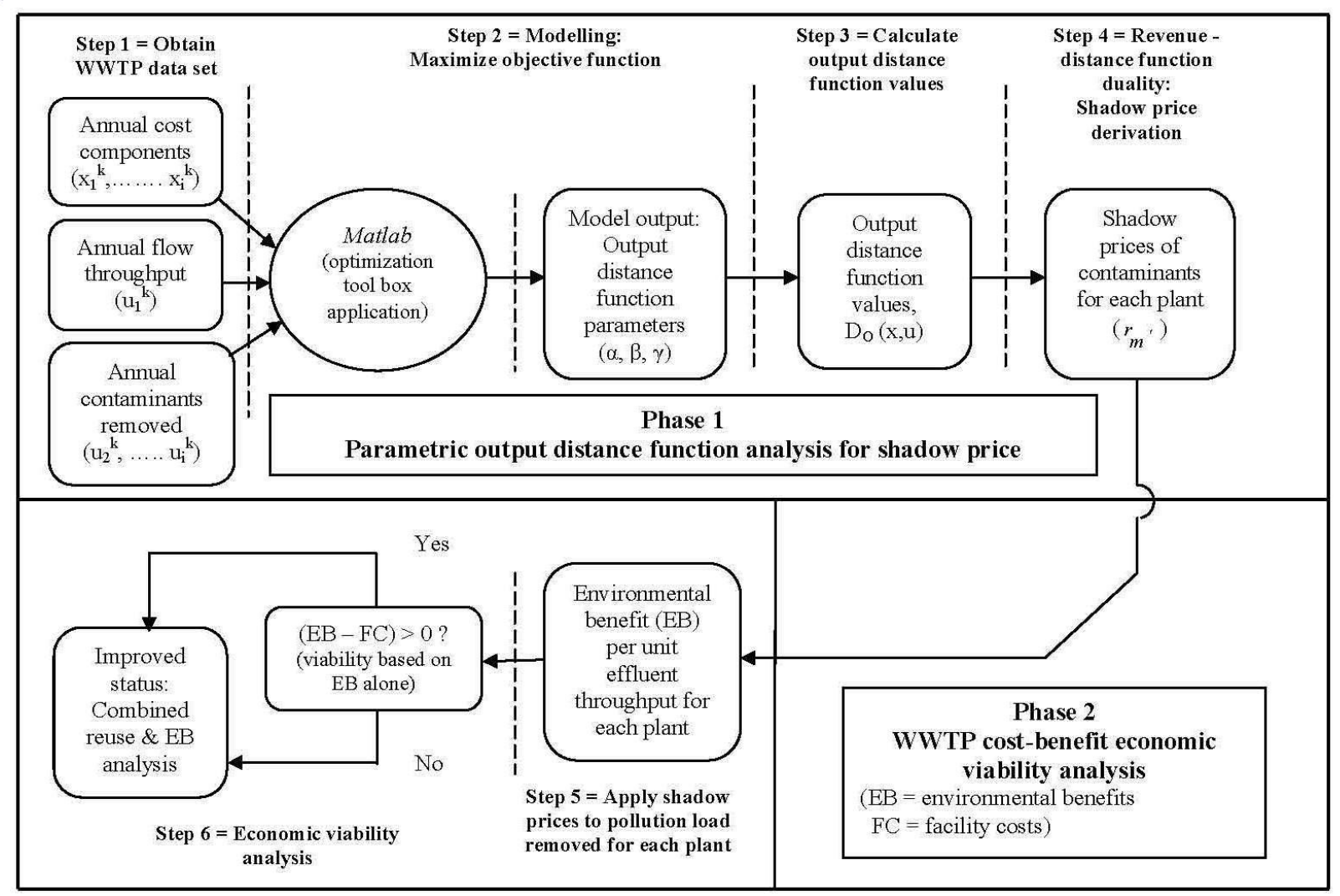

Fig. 5: Step sequence for environmental benefits valuing and cost-benefit analysis 


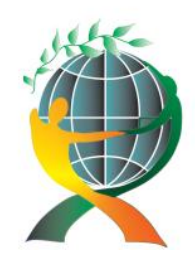

\author{
(online) $=$ ISSN $2285-3642$ \\ ISSN-L = $2285-3642$ \\ Journal of Economic Development, Environment and People \\ Volume 1, Issue 2, 2012
}

URL: http://jedep.spiruharet.ro

e-mail: office jedep@spiruharet.ro

Table 4: Distance function valuing of environmental benefits of plants in ZAR/m3

\begin{tabular}{|c|c|c|c|c|c|c|}
\hline \multirow{2}{*}{ WWTP's } & \multirow{2}{*}{$\begin{array}{c}\text { Annual } \\
\text { effluent } \\
\text { throughput } \\
\left(\mathrm{m}^{3}\right)\end{array}$} & \multicolumn{5}{|c|}{$\begin{array}{l}\text { Environmental benefits (EB) in } \mathrm{ZAR} / \mathrm{m}^{3} \text { and } \% \text { contribution } \\
\text { (Based on absolute price of treated effluent }=\mathrm{ZAR} 1 / \mathrm{m}^{3} \text { ) }\end{array}$} \\
\hline & & COD & SS & $\mathbf{N}$ & $\mathbf{P}$ & Total \\
\hline \multirow{2}{*}{ Plant 1} & \multirow{2}{*}{256,780} & 0.033213 & 0.044440 & 0.047800 & 0.043152 & 0.168605 \\
\hline & & $(19.70 \%)$ & $(26.36 \%)$ & $(28.35 \%)$ & $(25.59 \%)$ & \\
\hline \multirow{2}{*}{ Plant 2} & \multirow{2}{*}{$31,636,780$} & 0.057322 & 0.072197 & 0.040873 & 0.047951 & 0.218344 \\
\hline & & $(26.25 \%)$ & $(33.07 \%)$ & $(18.18 \%)$ & $(21.96 \%)$ & \\
\hline \multirow{2}{*}{ Plant 3} & \multirow{2}{*}{$21,407,700$} & 0.066401 & 0.093532 & 0.027689 & 0.038258 & 0.225879 \\
\hline & & $(29.40 \%)$ & $(41.41 \%)$ & $(12.26 \%)$ & $(16.94 \%)$ & \\
\hline \multirow{2}{*}{ Plant 4} & \multirow{2}{*}{$14,800,440$} & 0.041862 & 0.028328 & 0.050086 & 0.029494 & 0.149770 \\
\hline & & $(27.95 \%)$ & $(18.91 \%)$ & $(33.44 \%)$ & $(19.69 \%)$ & \\
\hline \multirow{2}{*}{ Plant 5} & \multirow{2}{*}{$4,090,020$} & 0.028168 & 0.034316 & 0.058967 & 0.047021 & 0.168472 \\
\hline & & $(16.72 \%)$ & $(20.37 \%)$ & $(35.00 \%)$ & $(27.91 \%)$ & \\
\hline \multirow{2}{*}{ Plant 6} & \multirow{2}{*}{$5,822,860$} & 0.017740 & 0.019697 & 0.082755 & 0.065910 & 0.186101 \\
\hline & & $(9.53 \%)$ & $(10.58 \%)$ & $(44.47 \%)$ & $(35.42 \%)$ & \\
\hline \multirow{2}{*}{ Plant 7} & \multirow{2}{*}{$10,289,230$} & 0.039136 & 0.052232 & 0.055795 & 0.054111 & 0.201275 \\
\hline & & $(19.44 \%)$ & $(25.95 \%)$ & $(27.72 \%)$ & $(26.88 \%)$ & \\
\hline \multirow{2}{*}{ Plant 8} & \multirow{2}{*}{$46,491,640$} & 0.040559 & 0.060207 & 0.044934 & 0.043854 & 0.189554 \\
\hline & & $(21,40 \%)$ & $(31.76 \%)$ & $(23.71 \%)$ & $(23.14 \%)$ & \\
\hline \multirow{2}{*}{ Plant 9} & \multirow{2}{*}{$67,914,570$} & 0.059233 & 0.068017 & 0.027204 & 0.026198 & 0.180652 \\
\hline & & $(32.79 \%)$ & $(37.65 \%)$ & $(15.06 \%)$ & $(14.50 \%)$ & \\
\hline
\end{tabular}

Table 5: Contaminant load removed per unit throughput of WWTP's

\begin{tabular}{|l|c|c|c|c|}
\hline \multirow{2}{*}{ WWTP's } & \multicolumn{4}{|c|}{ Contaminants load removed $\left(\mathrm{kg} / \mathrm{m}^{3}\right)$} \\
\cline { 2 - 5 } & COD & SS & N & P \\
\hline Plant 1 & 1.062 & 0.507 & 0.019 & 0.007 \\
\hline Plant 2 & 1.177 & 0.498 & 0.030 & 0.006 \\
\hline Plant 3 & 0.925 & 0.831 & 0.012 & 0.004 \\
\hline Plant 4 & 0.395 & 0.098 & 0.008 & 0.001 \\
\hline Plant 5 & 0.587 & 0.159 & 0.016 & 0.003 \\
\hline Plant 6 & 0.288 & 0.107 & 0.015 & 0.003 \\
\hline Plant 7 & 0.841 & 0.275 & 0.029 & 0.006 \\
\hline Plant 8 & 0.536 & 0.182 & 0.013 & 0.003 \\
\hline Plant 9 & 0.647 & 0.232 & 0.014 & 0.003 \\
\hline
\end{tabular}




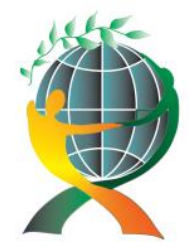

\author{
(online) $=$ ISSN $2285-3642$ \\ ISSN-L = 2285 - 3642 \\ Journal of Economic Development, Environment and People \\ Volume 1, Issue 2, 2012
}

URL: http://jedep.spiruharet.ro

e-mail: office jedep@spiruharet.ro

Table 6: Value ranking of plant suitability for nutrient recovery with agricultural reuse

\begin{tabular}{|c|c|c|}
\hline \multicolumn{2}{|c|}{$\begin{array}{l}\text { Agriculture reuse value ranking } \\
\text { (potential for nutrient recovery) }\end{array}$} & \multirow{2}{*}{$\begin{array}{l}\text { Nutrient ( } \mathrm{N} \text { and } \mathrm{P} \text { ) contribution to plant } \\
\text { total environmental benefits (\%) }\end{array}$} \\
\hline Ranking & Plant ID no. & \\
\hline 1 & 6 & 79.89 \\
\hline 2 & 5 & 62.91 \\
\hline 3 & 7 & 54.60 \\
\hline 4 & 1 & 53.94 \\
\hline 5 & 4 & 53.13 \\
\hline 6 & 8 & 46.85 \\
\hline 7 & 2 & 40.14 \\
\hline 8 & 9 & 29.56 \\
\hline 9 & 3 & 29.20 \\
\hline
\end{tabular}

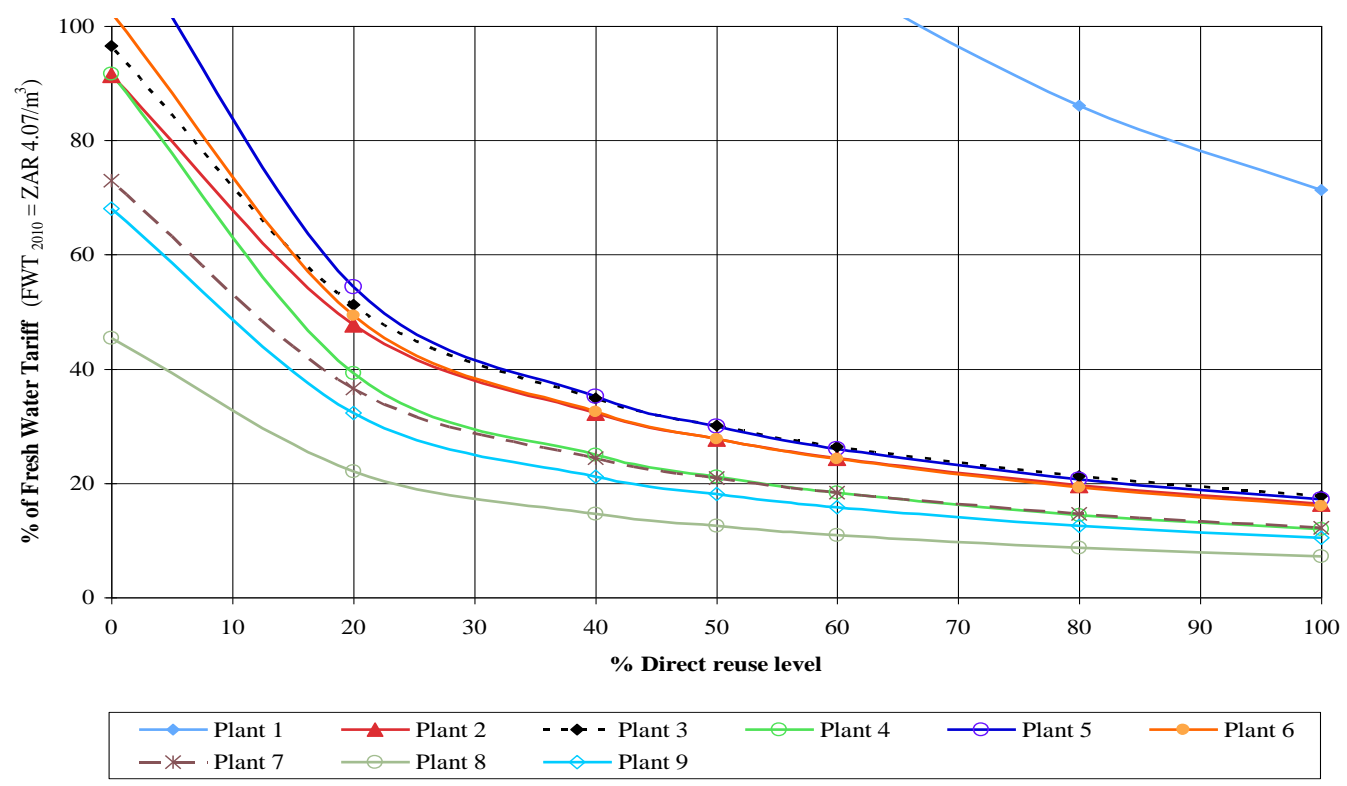

Fig.6: Plant cost-benefit breakeven tariffs as \% of current bulk fresh water tariff 


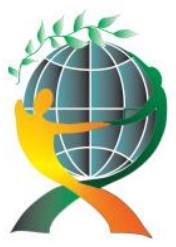

\author{
(online) $=$ ISSN $2285-3642$ \\ ISSN-L = $2285-3642$ \\ Journal of Economic Development, Environment and People \\ Volume 1, Issue 2, 2012 \\ URL: http://jedep.spiruharet.ro \\ e-mail: office jedep@spiruharet.ro
}

\section{Conclusions}

The economic viability analysis results illustrated in Figure 6 reveals the following:

Plant no's 1 and 7 require reuse levels of approximately 70 and 10\% of effluent for economic viability at $100 \%$ of fresh water tariff level.

The rest of the plants are economically viable based on internalized environmental benefits alone (i.e. no reuse required) at $100 \%$ of fresh water tariff level.

Generally (except Plant no. 1) for a reclamation or reuse level below roughly $20 \%$, the reuse tariff required for economic viability increases quite rapidly as reuse level decreases. For reuse of around 20 to about $50 \%$, the required reuse tariff flattens out and steadily declines for higher levels of reuse, confirming the fact that lower reuse tariff are possible in the event of higher reuse levels. The water reuse tariff obtained applies to plant level alone and need further adjustment for any conveyance system supply costs involved. For economic viability, this is likely to require higher treated effluent tariffs and reuse levels compared to those excluding conveyance costs.

It is clear from the contaminant shadow price data (Table 3 ) that the shadow price (in ZAR/kg) of phosphorus (P) is consistently highest for all plants, followed by nitrogen (N), suspended solids (SS) and organics (COD) the lowest. However, the opposite trend exists for contaminant load removed (in $\mathrm{kg} / \mathrm{m3}$ ) for all plants, i.e. P being the lowest, followed by N, SS and COD the highest (Table 5). This inverse trend between contaminant shadow price $(Z A R / \mathrm{kg})$ and its load removed $(\mathrm{kg} / \mathrm{m3})$ for the entire plants analyzed, i.e. high contaminant shadow price corresponding to a low contaminant load removed and visa versa confirms the soundness of the algorithm used. This amounts to a relative high marginal cost (shadow price) having to be incurred for every additional unit of removal of contaminants with current low load removed and vice versa.

Since the environmental benefit of removal of a particular contaminant is equal to the mathematical product of plant throughput and shadow price, environmental benefits and load removed are also inversely related. Therefore, where a large environmental benefit occurs, a low removed load applies or high remaining fraction of such contaminant in the treated effluent is present and vice versa. A value ranking of suitability of treatment plant effluent for agricultural reuse (Table 6) was derived by considering fractional environmental benefit contributions of nutrients ( $N$ and $P$ ) for plants, i.e effluent from plants with highest nutrient environmental benefit contributions would be most suitable for agricultural reuse application.

Distance function valuing provides a methodology for evaluation of economic effects and implication together with corresponding economic efficiency rankings as input to strategic decision making, of: different wastewater management system configurations accompanied by their potential for wastewater reclamation, reuse and recycling.

The effects of different technology option choices within any system configuration.

Switching from one management system configuration to another or from one set of technology options to another. 


\author{
(online) $=$ ISSN $2285-3642$ \\ ISSN-L = $2285-3642$ \\ Journal of Economic Development, Environment and People \\ Volume 1, Issue 2, 2012 \\ URL: http://jedep.spiruharet.ro \\ e-mail: office jedep@spiruharet.ro
}

\title{
6. References
}

[1] Al-Jayyousi, O.R. 2003, "Greywater reuse: towards sustainable water management", Desalination, vol. 156, no. 13, pp. 181-192.

[2] Birol, E., Karousakis, K. \& Koundouri, P. 2006, "Using economic valuation techniques to inform water resources management: A survey and critical appraisal of available techniques and an application", Science of The Total Environment, vol. 365, no. 1-3, pp. 105-122.

[3] Burton, S., Cohen, B., Harrison, S., Pather-Elias, S., Stafford, W., van Hille, R. \& von Blottnitz, H. 2009, Energy from Wastewater - a Feasibility study, WRC, South Africa.

[4] Christova-Boal, D., Eden, R.E. \& McFarlane, S. 1996, "An investigation into greywater reuse for urban residential properties", Desalination, vol. 106, no. 1-3, pp. 391-397.

[5] Dixon, A., Butler, D. \& Fewkes, A. 1999, "Water Saving Potential of Domestic Water Reuse Systems using Greywater and Rainwater in combination", Water Science and Technology, vol. 39, no. 5, pp. 25-32.

[6] Dolnicar, S. \& Shafer, A.I. 2009, "Desalinated versus recycled water: Public Perceptions and Profiles of the Accepters", Journal of Environmental Management, vol. 90, pp. 888-900.

[7] Eriksson, E., Auffarth, K., Henze, M. \& Ledin, A. 2002, "Characteristics of grey wastewater", Urban Water, vol. 4, no. 1, pp. 85-104.

[8] Färe, R., Grosskopf, S., Lovell, C.A.K. \& Yaisawarng, S. 1993, "Derivation of Shadow Prices for Undesirable Outputs: A Distance Function Approach", The review of economics and statistics, vol. 75, no. 2, pp. 374-380.

[9] Farrell, M.J. 1957, "The Measurement of Productive Efficiency", Journal of the Royal Statistical Society.Series A (General), vol. 120, no. 3, pp. 253-290.

[10] Gijzen, H.J. 1998, "Sustainable Wastewater Management via Re-use: Turning Waste into Wealth", Proc. AGUA98 Water and Sustainability July 1998 Cali Columbia, ed. M.e.a. Garcia, Cinara Institute Universidad Del Valle, Cali Columbia, pp. 211.

[11] Gijzen, H.J. 2001, "Anaerobes, aerobes and phototrophs A winning team for wastewater management", Water Science and Technology, vol. 44, no. 8, pp. 123-132.

[12] Haarhoff, J. \& van der Merwe, B. 1996, "Twenty-five years of Wastewater Reclamation in Windhoek Namibia", Water Science and Technology, vol. 33, no. 10, pp. 25-35.

[13] Lazarova, V., Hills, S. \& Birks, R. 2003, "Using recycled water for non-potable, urban uses: a review with particular reference to toilet flushing", Water Science \& Technology: Water Supply, vol. 3, no. 4, pp. 69-77.

[14] Lettinga, G., Lens, P. \& Zeeman, G. 2001, "Part 1: The DESAR concept for environmental protection. Section 1 Environmental Protection Technologies for Sustainable Development" in Decentralized Sanitation and Reuse Concepts, Systems and Implementation, eds. P. Lens, G. Zeeman \& G. Lettinga, IWA Publishing, , pp. 1-10. 


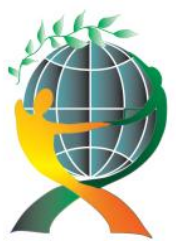

\author{
(online) $=$ ISSN $2285-3642$ \\ ISSN-L = $2285-3642$ \\ Journal of Economic Development, Environment and People \\ Volume 1, Issue 2, 2012 \\ URL: http://jedep.spiruharet.ro \\ e-mail: office jedep@spiruharet.ro
}

[15] Li, F., Wichmann, K. \& Otterpohl, R. 2009, "Evaluation of appropriate technologies for grey water treatments and reuses", Water Science \& Technology, vol. 59, no. 2, pp. 249-260. O’Donnell, C.J. \& Coelli, T.J. 2005, "A Bayesian approach to imposing curvature on distance functions", Journal of Econometrics, vol. 126, no. 2, pp. 493-523.

[16] Reynders C.C. (2011). A Methodology for Economic Assessment of Wastewater Intrinsic Value Recovery using an Indirect Production Function Approach. PhD thesis, University of the Witwatersrand, Johannesburg, South Africa.

[17] Reynders, C.C., Musiyarira, H. \& Marjanovic, P. 2010, "Development of a Decision Support System for Sustainable Wastewater Management in smaller South African municipalities", 11th WaterNET/WARFSA/GWP-SA Symposium 2010, 27-28 October 2010.

[18] Rocky Mountain Institute 2004, Valuing Decentralized Wastewater Technologies. A Catalog of Benefits, Costs, and Economic Analysis Techniques, Rocky Mountain Institute, Snowmass CO 81654 USA.

[19] Shephard, R.W. 1970, Theory of cost and production functions, (Princeton studies in mathematical economics), Princeton University Press.

[20] United Nations 2009, Department of Economic and Social Affairs; Population Division World Urbanization Prospects, the 2009 Revision. Available: http://esa.un.org/unpd/wup/index.htm [2011, $1 / 3 / 2011]$

[21] United Nations 2010, The Millenium Development Goals Report $2010 . \quad$ Available: http://www.un.org/millenniumgoals/reports.shtml [2011, 1/3/2011].

[22] UNEP/GEC 2004, Water and Wastewater Reuse - An Environmentally sound approach for Sustainable Urban Water Management, United Nations Environmental Programme (UNEP), The Hague, The Netherlands.

[23] WHO/UNEP 2006, Guidelines for the safe use of wastewater, excreta and greywater Volume 4, Excreta and greywater use in agriculture, WHO, Geneva, Switzerland. 